\title{
Findings of Phreatalona protzi (Hartwig, 1900) (Cladocera: Anomopoda: Chydoridae) in Russia
}

\author{
L.A. Frolova ${ }^{1 *}$, N.M. Nigmatullin ${ }^{1}$, A.A. Frolova ${ }^{1}$, L.B. Nazarova ${ }^{1,2}$ \\ ${ }^{1}$ Laboratory of Paleoclimatology, Paleoecology, Paleomagnetism, Kazan Federal University, \\ Kremlevskaya Street 18, Kazan 420008, Russia. \\ ${ }^{2}$ Institute of Geosciencies, University of Potsdam, Karl-Liebknecht-Str. 24-25, 14476 Potsdam- \\ Golm Germany. \\ *Corresponding author: larissa.frolova@mail.ru
}

ABSTRACT: We discovered subfossil remains of Phreatalona protzi (Hartwig, 1900) (Cladocera: Anomopoda: Chydoridae) in a short sediment core taken from a small tundra lake Pe-03 located in the Pechora River delta, North-East of European part of Russia. This species had been described previously only from Central and Northern Europe. The occurrence of P. protzi in the Russian Arctic suggests that this chydorid species must be much more widely distributed than previously reported, and in the near future we expect findings of this species in other regions of Russia.

How to cite this article: Frolova L.A., Nigmatullin N.M., Frolova A.A., Nazarova L.B. 2019. Findings of Phreatalona protzi (Hartwig, 1900) (Cladocera: Anomopoda: Chydoridae) in Russia // Invert. Zool. Vol.16. No.2. P.200-210. doi: 10.15298/invertzool. 16.2.07

KEY WORDS: Phreatalona protzi, Cladocera, Arctic, thermokarst lakes, Pechora Delta, paleolomnology.

\section{Находки Phreatalona protzi (Hartwig, 1900) (Cladocera: Anomopoda: Chydoridae) в России}

\author{
Л.А. Фролова ${ }^{1 *}$, Н.М. Нигматуллин ${ }^{1}$, А.А. Фролова', \\ Л.Б. Назарова ${ }^{1,2}$
}

\footnotetext{
${ }^{1}$ Лаборатория палеоклиматологии, палеоэкологии и палеомагнетизма, Казанский (Приволжский) федеральный университет, ул. Кремлевская 18, Казань, Республика Татарстан, 420008 Россия.

${ }^{2}$ Институт наук о земле, Потсдамский университет, ул. Карла Либкнехта.

*Автор для переписки: larissa.frolova@mail.ru
}

PЕЗЮМЕ: Субфоссильные остатки Phreatalona protzi (Hartwig, 1900) (Cladocera: Anomopoda: Chydoridae) были обнаружены в колонке донных отложений небольшого тундрового озера Ре-03, расположенного в дельте р. Печоры на северо-востоке европейской части России. Ранее находки данного вида отмечены только в Центральной и северной Европе. Обнаружение P. protzi в арктической зоне России предполагает, что данные вид хидорид распространен значительно шире, чем ранее сообщалось и следует ожидать в ближайшее его находок в других частях России. 
Как цитировать эту статью: Frolova L.A., Nigmatullin N.M., Frolova A.A., Nazarova L.B. 2019. Findings of Phreatalona protzi (Hartwig, 1900) (Cladocera: Anomopoda: Chydoridae) in Russia // Invert. Zool. Vol.16. No.2. P.200-210. doi: 10.15298/invertzool. 16.2.07

КЛЮЧЕВЫЕ СЛОВА: Phreatalona protzi, Cladocera, Арктика, термокарстовые озера, дельта Печоры, палеолимнология

\section{Introduction}

Cladocerans are microscopic branchiopod crustaceans occurring in all kinds of freshwater habitats from large lakes to ponds, and can be found even in small ditches, puddles and waterfilled tire ruts (Smirnov, 1971; Kotov et al., 2010). Cladocerans are a major component of the micro-crustacean fauna in freshwater waterbodies playing multiple roles in aquatic ecosystems (Korhola, Rautio, 2001).

Although the indicative potential of Cladocera as a paleolimnological proxy is well recognized (Smirnov, 1971; Kotov et al., 2019), cladoceran communities from Arctic regions of Russia received relatively little attention until now (Kienast et al., 2011; Frolova et al., 2014, 2017) because of their geographical remoteness and difficulties of access (Frolova et al., 2018). Sediment archives integrate Cladocera remains from all habitats: from pelagic, benthic and hyporheic zones of the lakes over several hundreds or thousands of years. Previous studies have shown that a single surface sediment sample could provide a more complete list of chydorid species than multiple hydrobiological samples from the contemporary environment (Frey, 1960; Davidson et al., 2007).

Surface sediments $(0-2 \mathrm{~cm})$ in each lake contain remains of the taxa deposited over the past few years, they are usually well preserved and can be identified (Solovieva et al., 2015; Syrykh et al., 2017). Paleolimnological methods of analysis improve our knowledge of the species biogeography by contributing to taxonomical resolution of the hardly accessible sites, where long-term hydrobiological studies are impossible (Nazarova et al., 2017a). This is especially important for small-sized cladoceran taxa, like chydorids as they may easily be overlooked in routine hydrobiological studies due to high diurnal, seasonal, spatial patchiness and difficulties of morphological identification(Nevalainen, 2010; Sweetman, Sarmaja-Korjonen, 2017).

Investigation of the cladocera remains from bottom sediments helps to clarify and expand our knowledge about the distribution of certain species of the cladocera (Nykänen, SarmajaKorjonen, 2007; Sweetman, Sarmaja-Korjonen, 2017). E.g., in the Kharbei lakes system(Bolshezemelskaya Tundra, Russia), Camptocercus rectrostris Schödler, 1862 was first discovered in a short sediment core taken from the lake Bolshoi Kharbei and only recently this species was found in modern zooplankton communities of this lake as well (Nazarova et al., 2014).

Unapertura latens was first described from the cores of some Scandinavian lakes (SarmajaKorjonen et al., 2000) and only recently an intact specimen was found. The species was placed in the genus Rhynchotalona (Van Damme, Nevalainen, 2019). Apparently, a chance of finding of rare species remains in sediments is sometimes higher than a chance of collecting living specimens by standard hydrobiological sampling methods.

The rare cladoceran Phreatalona protzi (Hartwig, 1900) (Anomopoda: Chydoridae) is among such species. Three specimens (2 females and 1 male) were collected in the coast zone of Lake Hellsee, near Biesenthal (Branderburg, Germany) by Dr. A. Protz, a curator of Konigsberg's Museum in 1889 (Hartwig, 1900). W. Hartwig named this new species in honour of Dr. A. Protz (Van Damme et al., 2009). Van Damme et al. (2009) relocated the species to the genus Phreatalona, as the species has some 
primitive features along with specialization to the rheic life mode.

After initial description, P. protzi was reported from Germany (Keilhack, 1911), England (1921), Slovakia (Vranovsky, 1971), Danube Delta in Romania (Negrea, 1966), Turkey (Dumont, Negrea, 1996), Poland and Lithuania (Flössner, 1972), France (Dumont, 1987), Ohrid Lake, Macedonia (Brancelj, Sket, 1990) and Belgium (Van Damme et al., 2009). Further to the East, it was found in the Voronezh Area of Russia (Smirnov, 1971) and in lakes of the Pripyat region of Belarus (Rassashko et al., 2013). The species was never found to the south of the Pyrenees, in the Alps, in the Taurus Mountains or east of the Ural Mountains (Bjerring et al., 2008; Kotov et al., 2010).

In sediment samples $P$. protzi was found for the first time in northern Denmark (Whiteside, 1970). In Finland the species was found both in zooplankton and in subfossil remains (Nykänen, Sarmaja-Korjonen, 2007). In this manuscript we report on the first finding of subfossil remains of Phreatalona protzi in Russia and provide environmental characteristics of the site where the species was found.

\section{Regional setting}

The Pechora River Basin is situated in Russia at the eastern border of Europe, west of the Ural Mountains, in the Komi Republic and Nenets Autonomous District of the Arkhangelsk Area. The study area is located beyond the Polar Circle, on the southern border of tundra landscape (Nelson, Anisimov, 1993). It belongs to the Malozemelskaya-Bolshezemelskaya province of the tundra and forest-tundra zones of the Russian Plain. In the delta there are lakes and duct fragments, as well as wetlands. Lakes of the region are mostly small in size (0.5-3.0 ha), are located in drainless depressions and have moraine or thermokarst origin. The lakes are mainly low-mineralized, oligotrophic and do not experience any anthropogenic impact (Solovieva et al., 2008; Nazarova et al., 2017b).

The climatic conditions of the study area are determined by the proximity of the sea, by the plain landscape and the fact that it is situated entirely north of the Polar Circle. Prevailing winds have south and southwest direction. The subarctic climate of the region is characterized by short and mild summers with a mean July temperature around $+13.5^{\circ} \mathrm{C}$ and severe winters with a mean January temperature $-17.2^{\circ} \mathrm{C}$. Annual precipitation is around $500 \mathrm{~mm}$. Snow cover lasts 219 days and snow has depth up to $93 \mathrm{~cm}$ (climate station, established in NaryanMar town in 1926, http://www.pogodaiklimat.ru/ climate/23205.htm). The territory is characterized by the presence of mainly discontinuous or patchy permafrost (Nikonova, 2015).

We analyzed surface sediment samples from 17 lakes, located in the delta of the Pechora River and a short sediment core taken from one of these lakes (Fig. 1). The short core was drilled in a study site located at $\mathrm{N} 68^{\circ} 11^{\prime} 31^{\prime \prime}$ and $\mathrm{E}$ $53^{\circ} 47^{\prime} 50^{\prime \prime} ; 1 \mathrm{~m}$ a.s.1. This small lake did not have an official name and during the field campaign received a technical name $\mathrm{Pe}-03$ that we use further through the text. It has a northeastsouthwest oriented elongated shape with a surface area of $c a 4.3$ ha and maximal size of $350 \times 250 \mathrm{~m}$ (Fig. 1). Its maximum depth is 2.0 $\mathrm{m}$. Our vegetation survey within the catchment area revealed that the southern shrub tundra here is dominated by Carex aquatilis, Arctophila fulva, Eriophorum scheuchzeri, Salix phylicifolia $(>2 \mathrm{~m})$, Salix sp. grows predominantly along the lake and river shoreline.

\section{Materials and methods}

Subfossil valves, head shields and postabdomens of $P$. protzi were extracted from the sediment core from the lake Pe-03 (Fig. 1). For coring a UWITEC gravity corer (Mondsee, Austria), equipped with $6 \mathrm{~cm}$ inner diameter and $60 \mathrm{~cm}$ length core liners, was used. A 48-cm sediment core was obtained from the water depth of $2.0 \mathrm{~m}$ in the deepest part of the lake in August 2017. The core was sectioned at 1-2$\mathrm{cm}$ intervals, which resulted in 26 sediment subsamples.

The lowermost sample of bulk sediments was AMS dated in the AMS Laboratory of 

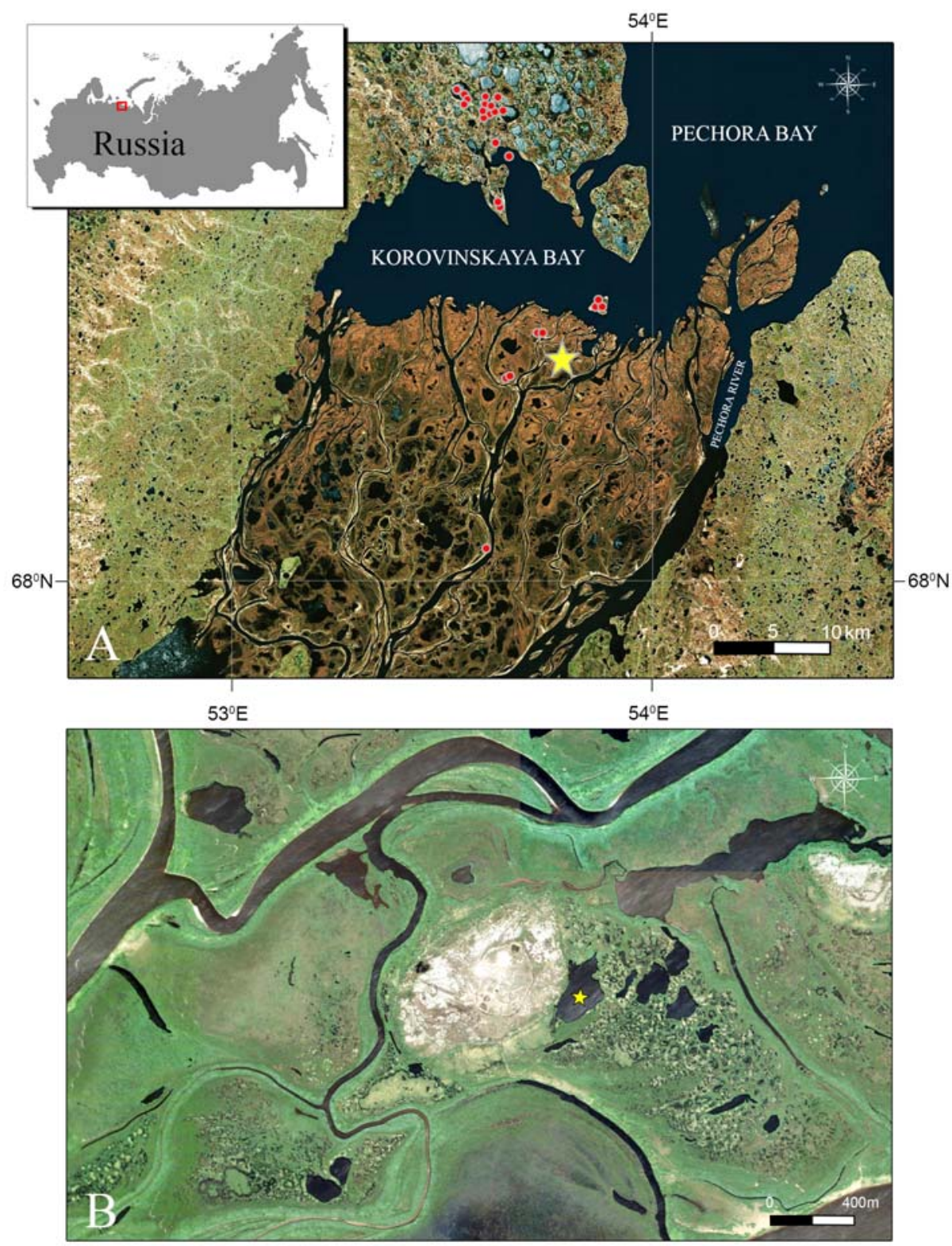

Fig. 1. Location of the studied lake:

A - Map of the Pechora Delta with the location of the Lake Pe-03 (star); B - Lake Pe-03 with the coring position. Рис. 1. Карта-схема расположения озера:

А — карта дельты Печоры с местоположением озера Ре-03 (звездочка); В — озеро Ре-03 с обозначенной точкой отбора колонки донных отложений.

Taiwan University. The uppermost sediment sample of core were analysed for ${ }^{210} \mathrm{~Pb}$ activity at the Geochronology Laboratory of St. Petersburg State University in order to obtain an additional timescale and to control the radiocarbon chronology. ${ }^{210} \mathrm{~Pb}$ found in the upper sediment samples, gave evidence for the modern age of the upper part of the core. 
Sediment samples were prepared for Cladocera analysis using the methods described by Frey (1986) and Korhola \& Rautio (2001). The samples ( $0.5 \mathrm{gr}$ in the upper part of the core and up to 7.8 gr of dry sediments in the bottom part of the core) were heated for approximately 30 minutes at $75^{\circ} \mathrm{C}$ in $10 \% \mathrm{KOH}$. The $\mathrm{KOH}$-sediment mixture was then poured onto a $50-\mu \mathrm{m}$ mesh sieve. A few drops of ethanol and safranin-glycerin solution were added to prevent fungal growth and to stain the cladoceran remains. The samples were then mounted on microscopic slides and analyzed for their cladoceran species composition under a light microscope Axiostar plus (Carl Zeiss) with magnifications of $100 x / 200 x / 400 x$. The chitinous remains of cladoceran (headshields, shells, postabdomens, postabdomenal claws and ephippia) were identified with reference to subfossil (Frey, 1982, 1986; Szeroczyńska, Sarmaja-Korjonen, 2007) and modern (Flössner, 1972, 2000; Smirnov, 1971, 1996; Kotov et al., 2010) cladoceran identification keys. Between 92 and 509 (mean 253) cladoceran remains per sample were counted from each sample. The most abundant body part was chosen for each species to represent the number of individuals, and 42-209 individuals were counted per sample. In subfossil Cladocera analyses, a minimum of 100 individuals has been proposed to be sufficient for describing the assemblages, although in low-richness lakes and lakes with low abundances of chydorids, a minimum count of 30 to 80 individuals likely reveals most of the occurring taxa (Kurek et al., 2010). The percentages for cladoceran species were calculated from this sum of individuals. A stratigraphic diagram was built in the program TILIA version2.0.b.4(Grimm, 1993).

\section{Results}

The analysis of the surface sediments from 17 lakes and of the short sediment core from the Pechora Delta (Fig. 1) lead to identification of 10695 cladoceran remains (headshields, valves, postabdomens, postabdomenal claws and ephippiua) that belonged to 35 taxa. Only in the small shallow lake Pe-03 we found remains of $P$. protzi. The lake has thermokarst origin, is shallow, has soft silty bottom with peat accumulation and dense underlying sandy layer. The near-shore area is covered by well-developed macrophyte belt. The oxygen saturation of the water during the study period was high (10.09 $\mathrm{mg} / \mathrm{l}), \mathrm{pH}$ was close to neutral (7.23) (Table). The lake water had a low mineralization and an extremely low conductivity. Bicarbonates and sodium ions prevailed (Table).

The $47.5 \mathrm{~cm}$-long sediment core covers $c a$. 2300 years of sedimentation. The relative abundances of cladocerans in the core are presented in Fig. 2. In the whole core a total of 6578 cladoceran remains (2943 individuals) of Cladocera were counted and identified. They represented 30 cladoceran taxa (24 Chydoridae). Bosmina (Eubosmina) longispina and Chydorus cf. sphaericus-type occurred in all samples. The cladoceran communities were dominated by Bosmina (E.) longispina (up to 67.50\%) and Chydorus cf. sphaericus (up to $47.67 \%$ ). Alonella nana (mean relatively abundance $5.83 \%$ ), Alona guttata/Coronatella rectangula (4.63\%), Alona quadrangularis $(4.43 \%)$, Disparalona rostrata $(3.36 \%)$ were quite common throughout the core. Other cladocerans were present at lower abundances.

$P$. protzi occurs in the core sporadically. We found remains of 23 individuals in 12 of 26 studied samples. In all samples this taxon was present at very low relative abundances, that varied between 0.7 and $4.0 \%$ (mean $0.35 \%$ ). In toto in the entire core we found 21 headshields, 5 valves and 3 postabdomens of $P$. protzi. Remains of $P$. protz $i$ were found in the uppermost part of core in the top centimeter of sediments. This allows us to assume that this species not only inhabited the lake in the past, but presumably can be found there nowadays as well.

We did not notice any morphological differences between the remains of $P$. protzi from the Pe-03 and the populations from Northern and Western Europe (Bjerring et al., 2008; Van Damme et al., 2009). All found head shields had a peculiar shape with a notched posterior margin and a short, broadly rounded rostrum (Bjerring et al., 2008) (Fig. 3). Valves of P. protzi can 
Table. Physical and limnological features of the lake Pe-03. Таблица. Физико-географические, лимнологические и геохимические параметры озера Pe-03.

\section{Location}

Altitude, $m$ a.s.l.

Surface area, ha

Fish status

$\mathrm{T}$ water, ${ }^{\circ} \mathrm{C}$

Depth $_{\max }, \mathrm{m}$

Conductivity, $\mu \mathrm{S} / \mathrm{cm}$

TDS, mg/l

$\mathrm{pH}$

$\mathrm{O}_{2}, \mathrm{mg} / \mathrm{l}$

$\mathrm{O}_{2}, \%$

$\mathrm{K}^{+}, \mathrm{mg} / \mathrm{l}$

$\mathrm{Na}^{+}, \mathrm{mg} / \mathrm{l}$

$\mathrm{Mg}^{2+}, \mathrm{mg} / \mathrm{l}$

$\mathrm{Ca}^{2+}, \mathrm{mg} / \mathrm{l}$

$\mathrm{Cl}^{-}, \mathrm{mg} / \mathrm{l}$

$\mathrm{SO}_{4}{ }^{2-}, \mathrm{mg} / \mathrm{l}$

$\mathrm{HCO}_{3}{ }^{-}, \mathrm{mg} / \mathrm{l}$

\section{$68^{\circ} 11^{\prime} 31^{\prime \prime} \mathrm{N} 53^{\circ} 47^{\prime} 50^{\prime \prime} \mathrm{E}$}

6.0

4.3

No fishes

15.4

2.0

54.10

54.00

7.23

10.09

100.50

0.98

12.90

1.83

4.75

1.56

5.45

13.46

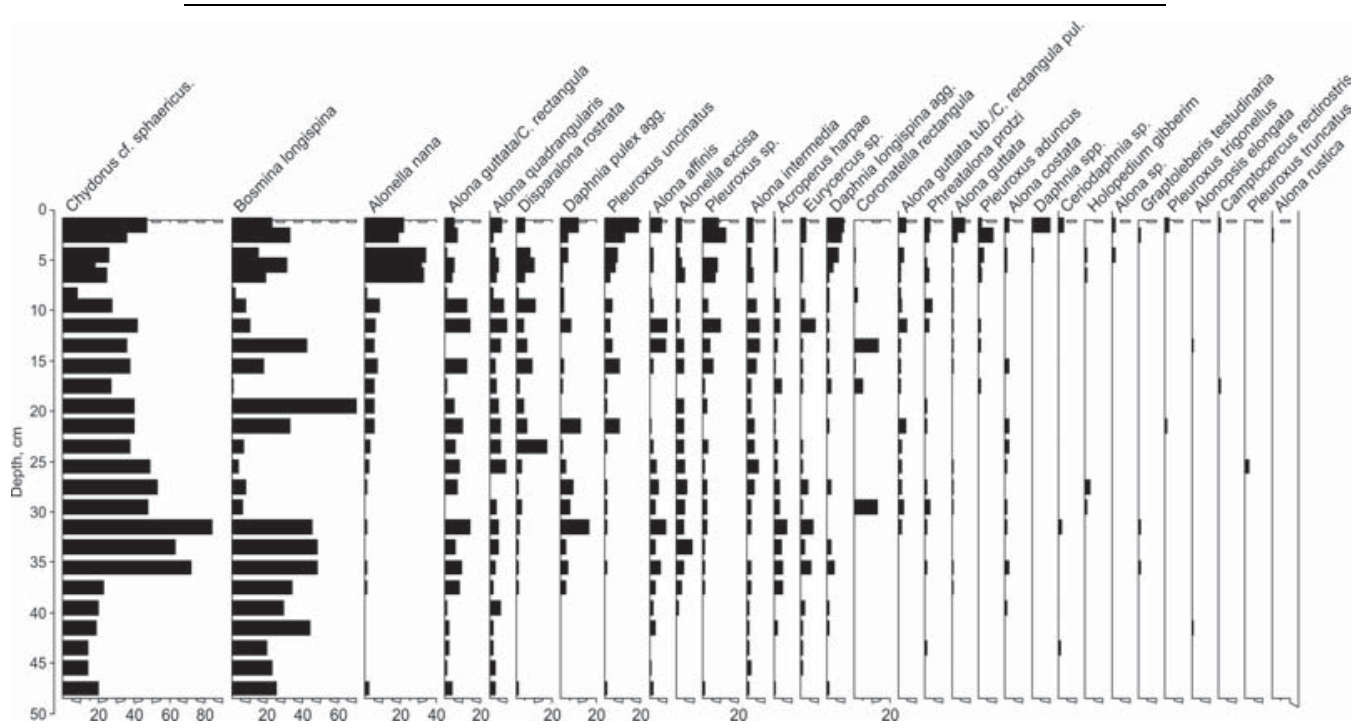

Fig.2. Relative abundance of Cladocera in the Pe- 03 core.

Рис. 2. Относительная численность Cladocera в колонке донных отложений озера Ре-03. 

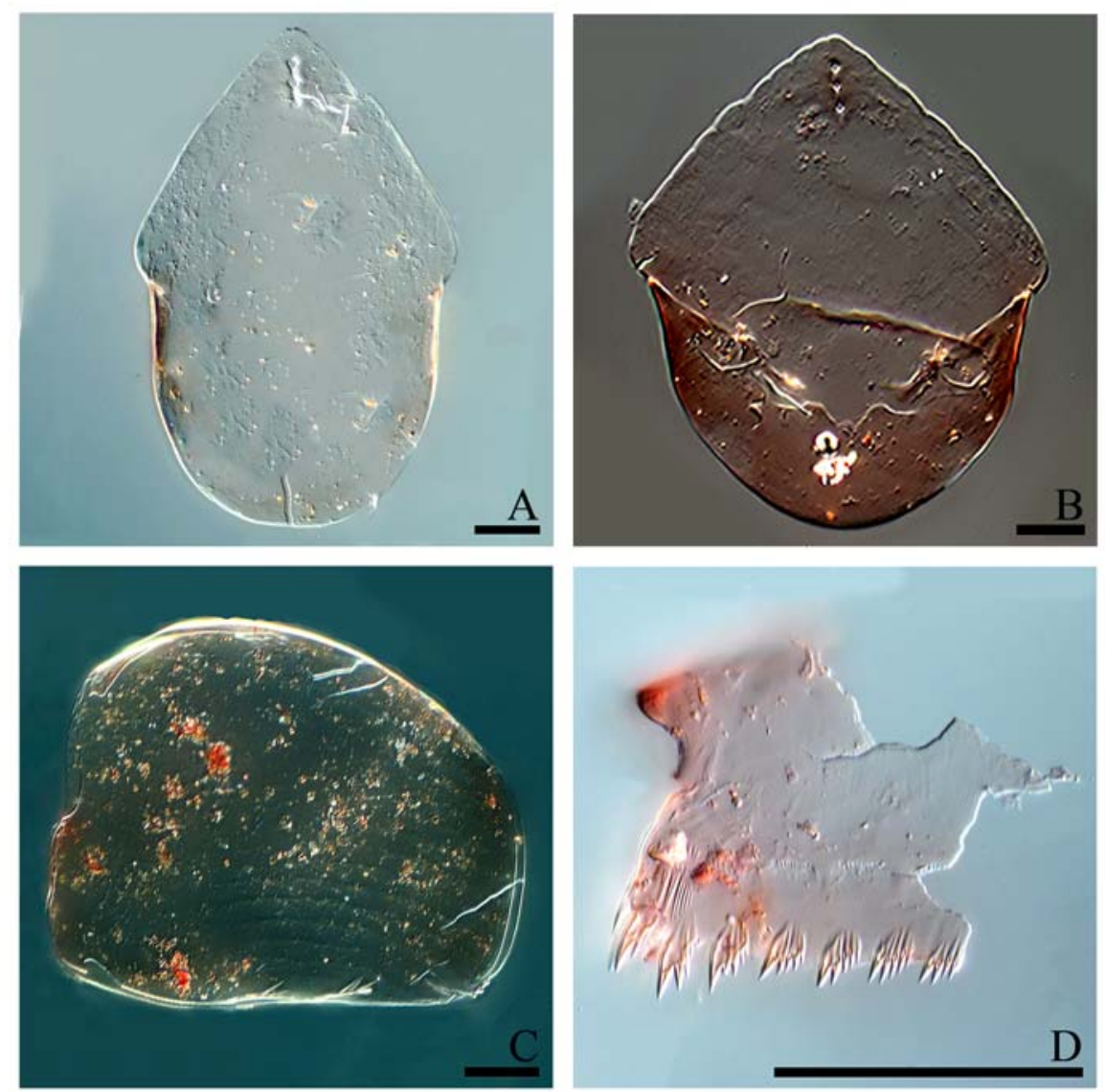

Fig. 3. Phreatalona protzi (Hartwig, 1900), from the lake Pe-03, Pechora Delta, Russia, female: A-B - subfossil head shields; C - carapace; D - postabdomen. Scale bars: $0.1 \mathrm{~mm}$ for A-D.

Рис. 3. Phreatalona protzi (Hartwig, 1900) из озера Ре-03, дельта Печоры, Россия, самка:

A-B - субфоссильные головные щиты; C - карапакс; D - постабдомен. Масштабные линейки: 0,1 мм для A-D.

be recognized easily as this is the only smallsized European Alona-like species with 2-3 denticles on postero-ventral angle of the shell of the carapace (Van Damme, 2010). The only other Alona species with denticles is $A$. affinis (Leydig, 1860) var. dentata, but it is much larger than $P$. protzi, the length of adult specimen of which exceeds $0.7 \mathrm{~mm}$ (Smirnov, 1971; Bjerring et al., 2008).

\section{Discussion}

P. protzi remains were found in the sediments of Russia lakes for the first time. Previous studies of sediments of numerous lakes in northern and central Russia, conducted by the authors (Frolova et al., 2014, 2016, 2017; Ibragimova et al., 2018, 2019), did not revealed any subfossil remains of $P$. protzi. Evidently, the rarity of the species findings is caused by a peculiar ecology and specific requirements to habitats of the species.

Our data confirm the occurrence of P. protzi in Russia, where reports of this species are relatively rare. Due to inaccurate translation of the original species description (Hartwig, 1900) from German, some authors mistakenly presumed the first finding of this species in Koenigs- 
berg (now Kaliningrad, Russia) (Van Damme et al., 2009, 2010), although the Koenigsberg was mentioned in the text only as the working place of Dr. A. Protz but not as the typical location of the species. Bening (1941) reported P. protzi from Caucasus, but this record is doubtful and was never confirmed by later investigations. Smirnov (1971) recorded $P$. protzi in a small stream Olkhovets, Voronezh Area, Central European part of Russia. Lazareva et al. (2018) reported P. protzi in the list of pelagic zooplankton from Saratov reservoir (lower part of the river Volga). Both last references do not provide an exact position of the sampling sites where P. protzi was found.

Flössner (1972) defines the distribution of P. protzi as Palaearctic, Dumont and Negrea (1996) as West Palearctic, and according to Van Damme et al. $(2009,2010)$ it is restricted to "Danubian Europe". According to Sinev (2017) $P$. protzi is an endemic of the Western Palearctic, not widespread in the Mediterranean region.

Even within Europe, P. protzi is rare, and its ecology is not fully studied (Nykänen, SarmajaKorjonen, 2007). The species inhabits predominantly hyporheic zone of rivers, so only few specimens are usually found during the sampling taken by standard methods (Van Damme et al., 2009). The species was found in abundance only during specialized sampling of the hyporheic zone, conducted by Van Damme et al. (2009), who found it in relatively high numbers $(>50)$ in two quarry locations near the River Maas (Maaseik, border Belgium-Germany) and in small branch of La Lanterne, an oligotrophic stream in Eastern France. Other occurrences of $P$. protzi belong to a variety of biotopes (Bjerring et al., 2008; Van Damme et al., 2009). In England a few living animals were found between Cordylophora in the running water of the river Ant (Gurney, 1921). Dumont (1983) found a small population of P. protzi in Turkey in a canal with stony walls and deep, wide cracks. In Slovakia some specimens were collected during zooplankton sampling in channels for filling rice bay, mostly in the littoral zone between Schoenoplectus (Vranovsky, 1971). In the Ohrid Lake $P$. protzi inhabits the algal mats on stones (Brancelj, Sket, 1990). In Denmark the species was found mostly in small clear lakes (Bjerring et al., 2008). Sporadically this species was found in lake littorals among dense submerged macrophytes (Nykänen, Sarmaja-Korjonen, 2007). Subfossil remains of $P$. protzi were found in rather variable habitats, from relatively nutrient poor, clear-water lakes to highly eutrophic lakes with neutral to alkaline $\mathrm{pH}$ and relatively low abundance of submerged macrophytes (Bjerring et al., 2008). Van Damme et al. (2009) suggests that findings of $P$. protzi remains in macrophyte rich lake littorals can occur if the lakes have inflowing springs or small streams, or have groundwater feed.

Nykänen \& Sarmaja-Korjonen (2007) presumed that presence of $P$. protzi remains has low value for paleolimnological reconstructions because of their rarity. In our opinion, presence of the species can have an important indicative value in paleolimnological research, as its occurence suggests a water inflow from river or stream and respectively existing of lotic conditions. Studied lake Pe-03 has no in- or outflow during the sampling time (August 2017), but it became connected with the river during spring floods. We suggest that findings of P. protzi remains can be seen as a signal of existing water flow or some connection between the lake and the river or stream. However, interpretation of the findings of $P$. protzi should be done with caution as it can be transported with water flow to an atypical environment.

The occurrence of P. protzi in the Pechora Delta in the Russian Arctic suggests that this species has a greater area of distribution than presumed previously; the species clearly is not restricted to "Danubian Europe". Systematic studies of subfossil Cladocera in Russian waterbodies in the future are very promising in terms of further records of $P$. protzi and other rare Chydoridae in other locations across Russia.

\section{Acknowledgements}

We are sincerely grateful to the staff members of the National Nenets Nature Reserve for their support in organization and conducting of our field work. We are grateful to K. Van 
Damme and A.Yu. Sinev for their help in identification of remains of $P$. protzi and R.J. Shiel for linguistic corrections in earlier draft. The field work was supported by the Russian Science Foundation (grant 16-17-10118). The analysis of subfossil cladocerans, interregional comparison, and interpretation of the results was supported by the Russian Foundation for Basic Research (grant 18-05-00406 A) as well as by the Russian Government Program of Competitive Growth of Kazan Federal University. The paper is dedicated to the 80th anniversary of A.V. Sher.

\section{References}

Anisimov O.A., Nelson F.E. 1993. [Zonality of the cryolithic zone of Russia under anthropogenic climate] // Meteorologiya i Gidrologiya. Vol.10. P.70-74 [in Russian].

Behning A.L. 1941. [Cladocera of the Caucasus]. Tbilisi: Gruzmedgiz. Publ. 384 p. [In Russian]

Bjerring R., Nykänen M., Sarmaja-Korjonen K., Sinev A., Jensen K., Nevalainen L., Szeroczyńska K., Zawisza E. 2008. Description of the subfossil head shield of Alona protzi Hartwig 1900 (Anomopoda, Chydoridae) and the environmental characteristics of its finding sites // Studia Quaternaria. Vol.25. P.47-53.

Brancelj A., Sket B. 1990. Occurrence of Cladocera (Crustacea) in subterranean waters in Yugoslavia // Hydrobiologia. Vol.199. No.1. P.17-20.

Davidson T.A, Sayer C.D, Perrow M.R, Bramm M., Jeppesen E. 2007. Are the controls of species composition similar for contemporary and sub-fossil cladoceran assemblages? A study of 39 shallow lakes of contrasting trophic status // Journal of Paleolimnology. Vol.38. P.117-134.

Dumont H.J. 1983. Discovery of groundwater-inhabiting Chydoridae (Crustacea: Cladocera), with the description of two new species // Hydrobiologia. Vol.106. Đ.97-106.

Dumont H.J. 1987. Groundwater Cladocera: a synopsis // Hydrobiologia. Vol.145. P.169-173.

Dumont H.J., Negrea S. 1996. A conspectus of the Cladocera of the subterranean waters of the world // Hydrobiologia. Vol.325. P.1-30.

Flössner D. 1972. Krebstiere, Crustacea. Kiemen und Blatfüsser, Branchiopoda, Fischläuse, 612 Branchiura // Tierwelt Deutschland. Lfg.60. $501 \mathrm{~S}$.

Flössner D. (ed.). 2000. Die Haplopoda und Cladocera (ohne Bosminidae) Mitteleuropas. Leiden: Backhuys Publ. 428 S.

Frey D.G. 1960. The ecological significance of cladoceran remains in lake sediments // Ecology. Vol.41. P.684699.

Frey D.G. 1982. The reticulated species of Chydorus (Cladocera, Chydoridae): two new species with sug- gestion of convergence // Hydrobiologia. Vol.93. P.255-279.

Frey D.G. 1986. Cladocera analysis // Handbook of Holocene Paleoecology and Paleohydrology. Vol.32. P.667-692.

Frolova L.A. 2018. Cladocera from bottom deposits as an indicator of changes in climate and ecological conditions // IOP Conference Series: Earth and Environmental Science. Vol.107. Is.1. No.012084. P.521524.

Frolova L., Ibragimova A., Fedorova I. 2016. Stratigraphy of Cladocera in a core from Yamal Peninsula Lake (Arctic Russia) // 16th International Multidisciplinary Scientific GeoConference SGEM. Conference Proceedings. Vol.2. P.579-586.

Frolova L.A., Ibragimova A.G., Ulrich M., Wetterich S. 2017. Reconstruction of the history of a thermokarst lake in the Mid-Holocene based on an analysis of subfossil Cladocera (Siberia, Central Yakutia) // Contemporary Problems of Ecology. Vol.10. No.4. P.423-430.

Frolova L., Nazarova L., Pestryakova L., Herzschuh U. 2014. Subfossil Cladocera from surface sediment in thermokarst lakes in northeastern Siberia, Russia, in relation to limnological and climatic variables // Journal of Paleolimnology. Vol.22. P.107-119.

Grimm E.C. 1993. TILIA 2.0.b.4 (Computer software). Springfield: Illinois StateMuseum, Research and Collections Center.

Gurney B. 1921. Two new British Entomostraca // Annals and Magazine of Natural History. Ser.9. Vol.7. P.236243.

Hartwig W. 1900. Eiene neue Alona aus der Provinz Brandenburg: Alona protzi Hartwig sp.n // Sitzungsberichte der Gesellschaft Naturforschender Freunde zu Berlin. Bd.10. S.228-230.

Ibragimova A.G., Frolova L.A., Kosareva L.R., Kotov A.A., Nurgaliev D.K. 2019. [The taphocoenosis of cladocerans in lake Rubskoe, Ivanovo Region, European part of the Russian Federation] // Zool. Zhur. Vol.98. No.6. P.1-11 [in Russian].

Ibragimova A.G., Frolova L.A., Subetto D.A., Belkina N.A., Potakhin M.S. 2017. The changes in the composition of Cladocera community in bottom sediments of Lake Maloye Shibrozero (Zaonezhsky Peninsula) as a consequence of shifts of environmental and climatic conditions // IOP Conference Series: Earth and Environmental Science. Vol.107. Is.1. No.012029. P.174-181.

Kienast F., Wetterich S., Kuzmina S., Schirrmeister L., Andreev A., Tarasov P., Nazarova L., Kossler A., Frolova L., Kunitsky V. 2011. Paleontological records prove boreal woodland under dry inland climate at today's Arctic coast in Beringia during the last interglacial// Quaternary Science Reviews. Vol.30. P.21342159.

Keilhack L. 1911. Beiträge zur Kenntnis dreier seltener Alonen aus Norddeutschland // Archiv fûr Hydrobiologie / Planktonkunde. Bd.6. S.467-474.

Korhola A., Rautio M. 2001. Cladocera and other branchiopod crustaceans // J.P. Smol, J.B. Birks, W.M. Last 
(eds). Tracking Environmental Change Using Lake Sediments. Zoological Indicators. Dordrecht: Kluwer. Vol.1. P.5-41.

Kotov A.A., Kuzmina S.A., Frolova L.A., Zharov A.A., Neretina A.N., Smirnov N.N. 2019. Ephippia of the Daphniidae (Branchiopoda: Cladocera) in Late Caenozoic deposits: untapped source of information for palaeoenvironment reconstructions in the Northern Holarctic // Invert. Zool. Vol.16. No.2. P.183-199.

Kotov A.A., Sinev A.Yu., Glagolev S.M., Smirnov N.N. 2010. [Cladocerans (Cladocera)] // V.R. Alekseev, S.Ja. Tzalolikhin (eds.). Opredelitel' zooplanktona i zoobentosa preshykh vod Evropeiskoi Rossii. Vol.1. Zooplankton. Moscow: KMK Sci. Press. P.151-276 [in Russian].

Kurek J., Korosi J.B., Jeziorski A., Smol J.P. 2010. Establishing reliable minimum count sizes for cladoceran subfossils sampled from lake sediments // Journal of Paleolimnology. Vol.44. P.603-612.

Lazareva V.I., Sabitova R.Z., Sokolova E.A. 2018. [Features of the structure and distribution of the late summer (august) zooplankton in the Volga reservoirs] // Trudy Instituta Biologii Vnutrennich Vod imeni I.D. Papanina RAN. Is. 82(85). P.28-52 [in Russian].

Nazarova L.B., Frolova L.A., Kosareva L.R., Rudaya N.A., Syrykh L.S., Gafiatullina L.I., Kuzina D.M., Palagushkina O.V., Tumanov O.N., Fefilova E.B., Loskutova O.A. 2014. [Magnetical-mineralogical and biological indicators of bottom sediments in the Big Harbey lake] // Zhurnal Sibirskogo Federal'nogo Universiteta. Seria Biologia. Vol.7. P.372-394 [in Russian].

Nazarova L., Grebennikova T.A., Razjigaeva N.G., Ganzey L.A., Belyanina N.I., Arslanov K.A., Kaistrenko V.M., Gorbunov A.O., Kharlamov A.A., Rudaya N., Palagushkina O., Biskaborn B.K., Diekmann B. 2017. Reconstruction of Holocene environmental changes in Southern Kurils (North-Western Pacific) based on palaeolake sediment proxies from Shikotan Island // Global and Planetary Change. Vol.159. P.25-36.

Nazarova L.B., Self A.E., Brooks S.J., Solovieva N., Syrykh L.S., Dauvalter V.A. 2017. Chironomid fauna of the lakes from the Pechora River basin (East of European part of Russian Arctic): ecology and reconstruction of recent ecological changes in the region // Contemporary problems of Ecology. No.4. P.350362 .

Negrea S. 1966. Autökologische Untersuchungen über die Cladocerenfauna des Überschwemmungs-Gebietes der Donau (im Crapina-Jijila Flachseenkomplex) // Archiv für Hydrobiologie Supplement. Bd.30. S.115160.

Nevalainen L. 2010. Evaluation of microcrustacean (Cladocera, Chydoridae) biodiversity based on sweep net and surface sediment samples // Ecoscience. Vol.17. P.356-364.

Nikonova A.N. 2015. [Transformation of floodplain ecosystems of the Pechora River delta within the impact zone of the Kumzhinskoe Gas Condensate Field (Nenets Autonomous Okrug)] // Izvestiya RAN. Seriya Geograficheskaya. No.5. P.117-129 [in Russian].
Nykänen M., Sarmaja-Korjonen K. 2007. Findings of Alona protzi Hartwig, 1900 (Branchiopoda: Anomopoda: Chydoridae) in Finland // Studia Quaternaria. Vol.24. P.73-77.

Rassashko I.F., Kovaleva O.V., Vezhnovec V.V. 2013. [Biodiversity and geographic distribution of cladocerans (Cladocera) in the aquatic ecosystems of Belarusian Polesye] // Izvestiya Gomelskogo gosudarstvennogo universiteta imeni F. Skoriny. Esstestvennye nauki. No.5(80). P.136-142 [in Russian].

Sarmaja-Korjonen K., Hakojärvi M., Korhola A. 2000. Subfossil remains of an unknown chydorid (Anomopoda: Chydoridae) from Finland // Hydrobiologia. Vol.436. P.165-169.

Sinev A.Yu. 2017. [Morphology, taxology and zoogeography of cladocerans of the subfamily Aloninae (Cladocera: Anomopoda: Chydoridae)]: dissertatsiya... doctora biologicheskikh nauk. Moscow: Moscovskiy Gosudarsvenniy Universitet. 433 p. [In Russian]

Smirnov N.N. 1971. [Chydoridae of the world] // Fauna SSSR. Rakoobraznye. Vol.1. Leningrad: Nauka. 531 p. [In Russian]

Smirnov N.N. 1996. Cladocera: the Chydorinae and Sayciinae (Chydoridae) of the World // H.J.F. Dumont (ed.). Guide to Identification of Macroinvertebrates of the Continental Waters of the World. Amsterdam: Backhuys Publ. Vol.11. P.1-197.

Solovieva N., Jones V.J., Birks H.J.B., Appleby P.G., Nazarova L. 2008. Diatom responses to 20th century climate warming in lakes from the northern Urals, Russia // Palaeogeography, Palaeoclimatology, Palaeoecology. Vol.259. P.96-106.

Solovieva N., Klimaschewski A., Self A.E., Jones V.J., Andrén E., Andreev A.A., Hammarlund D., Lepskaya E.V., Nazarova L. 2015. Holocene environmental history of a small coastal lake from north-eastern Kamchatka Peninsula // Global and Planetary Change. Vol.134. P.55-66.

Sweetman J.N., Rühland K.M., Smol J.P. 2010. Environmental and spatial factors influencing the distribution of cladocerans in lakes across the central Canadian Arctic treeline region // Journal of Limnology. Vol.69. P.1-12.

Sweetman J.N., Sarmaja-Korjonen K. 2017. First evidence for the occurrence of Unapertura (Crustacea, Branchiopoda, Anomopoda, Chydoridae) in North America based on subfossil remains // Journal of Paleolimnology. Vol.58. P.291-297.

Syrykh L.S., Nazarova L.B., Herzschuh U., Subetto D.A., Grekov I.M. 2017. Reconstruction of palaeoecological and palaeoclimatic conditions of the Holocene in the south of Taimyr according to the analysis of lake sediments // Contemporary Problems of Ecology. No.4. P.363-369.

Szeroczyńska K., Sarmaja-Korjonen K. 2007. Atlas of Subfossil Cladocera from Central and Northern Europe. Ewiecie: Friends of the Lower Vistula Society. $83 \mathrm{p}$.

Van Damme K., Brancelj A., Dumont H.J. 2009. Adaptations to the hyporheic in Aloninae (Crustacea: Cla- 
docera): allocation of Alona protzi Hartwig, 1900 and related species to Phreatalona gen.n. // Hydrobiologia. Vol.618. P.1-34.

Van Damme K., Kotov A.A., Dumont H.J. 2010. A checklist of names in Alona Baird, 1843 (Crustacea: Cladocera: Chydoridae) and their current status: an analysis of the taxonomy of a lump genus // Zootaxa. Vol.2330. P.1-63.

Van Damme K., Nevalainen L. 2019. The most latent cladoceran in the holarctic revealed - sinking Unapertura Sarmaja-Korjonen, Hakojärvi, Korhola 2000 into Rhynchotalona Norman, 1903 (Branchiopoda: Cladocera: Chydoridae) // Zootaxa (accepted).

Vranovsky M. 1971. Über das Vorkommen von Alona protzi Hartwig (Cladocera) in der Südwestlichen Slowakei // Věstník československé společnosti zoologické. Bd.3. S.229-233.

Whiteside M.C. 1970. Danish chydorid cladocera: modern ecology and core studies // Ecological Monographs. Vol.40. P.79-118.

Responsible editor A.A. Kotov 